\title{
Iron limitation of a springtime bacterial and phytoplankton community in the Ross Sea: implications for vitamin $B_{12}$ nutrition
}

\author{
Erin M. Bertrand', Mak A. Saito ${ }^{*}$, Peter A. Lee ${ }^{3}$, Robert B. Dunbar ${ }^{4}$ Peter N. Sedwick ${ }^{5}$ and \\ Giacomo R. DiTullio ${ }^{6}$
}

\author{
MITMHOI Joint Program in Chemical Oceanography and Marine Chemistry and Geochemistry Department, Woods Hole Oceanographic Institution, Woods Hole, \\ MA, USA \\ ${ }^{2}$ Marine Chemistry and Geochemistry Department, Woods Hole Oceanographic Institution, Woods Hole, MA, USA \\ ${ }^{3}$ Hollings Marine Laboratory, College of Charleston, Charleston, SC, USA \\ ${ }^{4}$ Department of Environmental Earth Systems Science, Stanford University, Stanford, CA, USA \\ ${ }^{5}$ Department of Ocean, Earth and Atmospheric Sciences, Old Dominion University, Norfolk, VA, USA \\ ${ }^{6}$ Hollings Marine Laboratory, College of Charleston, Charleston, SC, USA
}

\section{Edited by:}

Karla B. Heidelberg, University of Southern California, USA

\section{Reviewed by:}

Chris Gobler, Stony Brook University USA

Sergio Sanudo-Wilhelmy, University of Southern California, USA

*Correspondence:

Mak A. Saito, Marine Chemistry and Geochemistry Department, Woods Hole Oceanographic Institution, 360 Woods Hole Road, Woods Hole, MA 02543, USA.

e-mail:msaito@whoi.edu
The Ross Sea is home to some of the largest phytoplankton blooms in the Southern Ocean. Primary production in this system has previously been shown to be iron limited in the summer and periodically iron and vitamin $\mathrm{B}_{12}$ colimited. In this study, we examined trace metal limitation of biological activity in the Ross Sea in the austral spring and considered possible implications for vitamin $B_{12}$ nutrition. Bottle incubation experiments demonstrated that iron limited phytoplankton growth in the austral spring while $\mathrm{B}_{12}$, cobalt, and zinc did not. This is the first demonstration of iron limitation in a Phaeocystis antarctica-dominated, early season Ross Sea phytoplankton community. The lack of $\mathrm{B}_{12}$ limitation in this location is consistent with previous Ross Sea studies in the austral summer, wherein vitamin additions did not stimulate $P$. antarctica growth and $\mathrm{B}_{12}$ was limiting only when bacterial abundance was low. Bottle incubation experiments and a bacterial regrowth experiment also revealed that iron addition directly enhanced bacterial growth. $B_{12}$ uptake measurements in natural water samples and in an iron fertilized bottle incubation demonstrated that bacteria serve not only as a source for vitamin $B_{12}$, but also as a significant sink, and that iron additions enhanced $\mathrm{B}_{12}$ uptake rates in phytoplankton but not bacteria. Additionally, vitamin uptake rates did not become saturated upon the addition of up to $95 \mathrm{pM} \mathrm{B}_{12}$. A rapid $\mathrm{B}_{12}$ uptake rate was observed after $13 \mathrm{~min}$, which then decreased to a slower constant uptake rate over the next $52 \mathrm{~h}$. Results from this study highlight the importance of iron availability in limiting early season Ross Sea phytoplankton growth and suggest that rates of vitamin $B_{12}$ production and consumption may be impacted by iron availability.

Keywords: iron limitation, vitamin $B_{12}$, Ross Sea, colimitation, bacteria, phytoplankton, iron fertilization

\section{INTRODUCTION}

The Ross Sea of the Southern Ocean (Figure 1) hosts massive phytoplankton blooms (Smith and Nelson, 1985) and high rates of dimethylsulfoniopropionate (DMSP) production (DiTullio and Smith, 1995). As a result, this and similar Antarctic coastal ecosystems are considered to have a significant impact on global biogeochemical cycles (Arrigo et al., 1999, 2008). The phytoplankton community in the Ross Sea is typically dominated by the colonial haptophyte Phaeocystis antarctica (DiTullio and Smith, 1996) and pennate diatoms such as Fragilariopsis and Pseudonitzschia spp. (Leventer and Dunbar, 1996; Arrigo et al., 1999; Armand et al., 2005). Because of the significantly higher C:P and N:P ratios of $P$. antarctica compared to diatom communities, the relative abundances of P. antarctica and diatoms in the Ross Sea may control carbon uptake and export in the region (Arrigo et al., 1999). These community dynamics are thought to be controlled in part by irradiance, with diatoms dominating when mixed layers are shallow (high irradiance, associated with sea ice meltwater), and $P$. antarctica dominating when mixed layers are deep (low irradiance; DiTullio and Smith, 1996; Arrigo et al., 1999).

Iron has been shown to exert a controlling influence on primary productivity in the Ross Sea, particularly in the austral summer months (Martin et al., 1990; Sedwick and DiTullio, 1997; Sedwick et al., 2000; Bertrand et al., 2007). Iron availability is also thought to impact Ross Sea phytoplankton community composition, as iron additions have in some cases caused substantive diatom blooms (Martin et al., 1990; Sedwick et al., 2000; Rose et al., 2009; Feng et al., 2010). However, other experiments have shown that field populations of $P$. antarctica may also benefit from iron addition (Olson et al., 2000; Coale et al., 2003; Bertrand et al., 2007). It has previously been suggested that elevated dissolved iron concentrations in the springtime, supplied by winter mixing and sea 


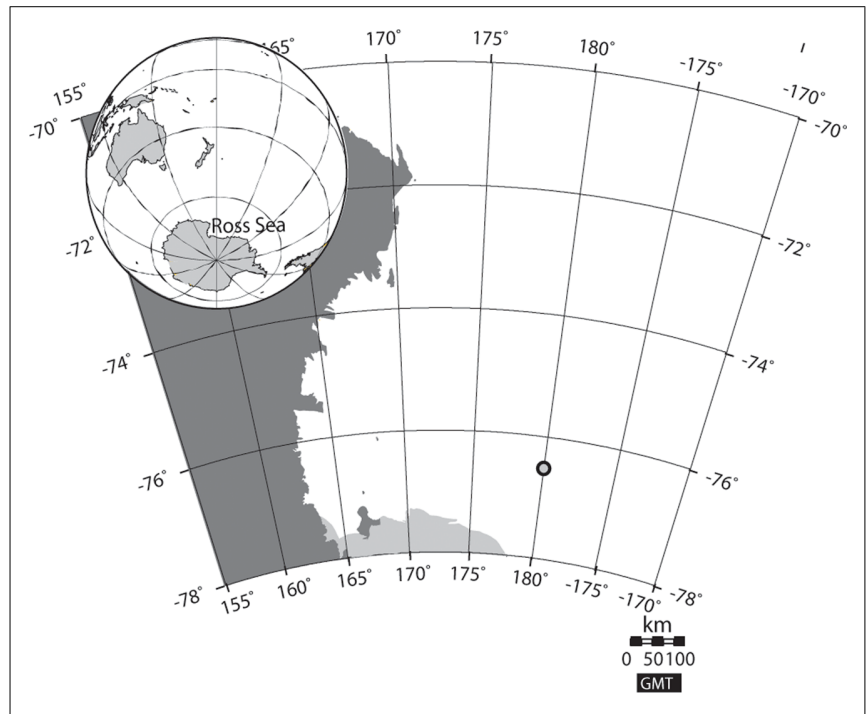

FIGURE 1 | Map of the Ross Sea, with inset globe for orientation, showing the location of the main experiments in this study station SP3, $76.50^{\circ} \mathbf{S} 179.99 W$. Light gray denotes the approximate location of the ice shelf, while dark gray denotes land.

ice melt, are progressively depleted via phytoplankton uptake, thus resulting in low dissolved iron concentrations and iron limitation of primary productivity during the summer Sedwick et al., 2000; Coale et al., 2005). However, more recent work revealed relatively low dissolved iron concentrations in the Ross Sea polynya during the spring, thus challenging the conceptual model of a gradual progression toward iron limitation of phytoplankton growth (Sedwick et al., in review).

There is increasing evidence that the availability of vitamin $\mathrm{B}_{12}$ can also play a role in shaping phytoplankton dynamics in Antarctic coastal ecosystems (Panzeca et al., 2006; Bertrand et al., 2007) as well as other environments including the Gulf of Alaska (Koch et al., 2011), Long Island embayments (Sañudo-Wilhelmy et al., 2006; Gobler et al., 2007), the Sargasso Sea (Menzel and Spaeth, 1962), and the Gulf of Maine (Swift, 1981). Shipboard bottle incubation experiments performed in the Ross Sea during austral summer 2005 demonstrated that vitamin $B_{12}$ became the limiting nutrient once iron was replete, but only in areas with low bacterial abundance (Bertrand et al., 2007). This scenario can be referred to as periodic secondary $\mathrm{B}_{12}$ limitation, or vitamin and iron colimitation (Saito et al., 2008). The addition of $B_{12}$ and iron also increased the percentage of diatoms in the bottle incubations relative to iron addition alone, suggesting that vitamin $B_{12}$ may help govern rates of primary production as well as phytoplankton species composition.

Vitamin $B_{12}$ is produced by some bacteria and archaea, while other prokaryotes as well as most eukaryotic phytoplankton require an exogenous supply of $\mathrm{B}_{12}$ to sustain growth (Roth et al., 1996; Rodionov et al., 2003; Croft et al., 2005; Tang et al., 2010). Those phytoplankton and bacteria that do not require vitamin $\mathrm{B}_{12}$ possess alternative biochemical pathways for accomplishing essential reactions, including use of a di-ferric form of ribonucleotide reductase (type $\mathrm{I}$ ) rather than the $\mathrm{B}_{12}$-requiring version (type II), and the use of zinc-requiring methionine synthase (MetE) rather than the version that requires vitamin $\mathrm{B}_{12}$ and zinc (MetH) (Zhang et al., 2009; Helliwell et al., 2011).

Biosynthesis of vitamin $\mathrm{B}_{12}$ requires over 30 enzymatic steps and appreciable amounts of energy, carbon, nitrogen, and transition metals including cobalt, zinc, and in some cases iron (Roth et al., 1996; Raux et al., 2000). Though some $B_{12}$ biosynthesis genes, potentially from an undescribed clade of gamma proteobacteria, have been detected in microbial communities from the Ross Sea (Bertrand et al., 2011), the genetic potential for vitamin $B_{12}$ production remains largely uncharacterized in the Ross Sea or in any other marine environment. This is in part because 16s rRNA profiling, which is commonly used for bacterial community structure analysis, does not provide information about vitamin $\mathrm{B}_{12}$ production potential, since the presence of the biosynthesis pathway among bacterial and archaeal lineages is widespread and extremely variable. An exception to this is the marine cyanobacteria, where all available sequenced genomes appear to contain the $\mathrm{B}_{12}$ biosynthetic pathway (Rodionov et al., 2003), and a range of strains have been shown to be produce significant amounts of $B_{12}$ (Bonnet et al., 2010). The Ross Sea and other Antarctic marine systems lack appreciable cyanobacterial populations (Caron et al., 2000; Marchant, 2005; Bertrand et al., 2011), leaving Antarctic marine systems potentially deficient in a source of this vitamin, making these regions particularly vulnerable to $\mathrm{B}_{12}$ limitation. In addition, genome sequences from representatives of the abundant heterotrophic bacterial clade SAR11 suggest that in addition to not producing vitamin $\mathrm{B}_{12}$ (Giovannoni et al., 2005), these microbes do not require the vitamin and do not possess known $\mathrm{B}_{12}$ uptake pathways (Zhang et al., 2009), implying that $\mathrm{B}_{12}$ independence may be part of the ecological niche of these abundant heterotrophic bacteria.

Either through cycling of the microbial loop (Karl, 2002; Droop, 2007) or through direct symbiotic interaction (Croft et al., 2005), bacteria and archaea must be the ultimate source of vitamin $\mathrm{B}_{12}$ to auxotrophic (vitamin-requiring) phytoplankton. Therefore, in areas of the ocean where vitamin $\mathrm{B}_{12}$ has been shown to be an important factor in determining phytoplankton growth or community composition, understanding the controls on primary productivity demands consideration of bacterial growth and dynamics. Although bacterial abundance and biomass can reach bloom proportions in the Ross Sea, bacterial production there is relatively low, especially during the austral spring (Ducklow et al., 2000, 2001). Ross Sea bacterial production is thought to be controlled by the availability of dissolved organic matter (DOM), with little direct impact of temperature (Ducklow et al., 2001). However, the role of iron in controlling bacterial production has yet to be fully investigated. Although it is possible for marine bacterial growth rates and efficiency to be limited by iron availability in cultures (Tortell et al., 1996), there has been little study of bacterial iron limitation in the field. Bacterial growth in the Southern Ocean has been observed to be DOM limited (Hall and Safi, 2001; Oliver et al., 2004), iron limited (Pakulski et al., 1996), and iron and DOM colimited (Church et al., 2000). Availability of DOM has been found to be the primary limiting factor for bacterial production in other iron limited HNLC (high nutrient low chlorophyll) areas (Hale et al., 2006), although in some regions 
iron quickly becomes limiting when organic carbon limitation is alleviated (Kirchman et al., 2000). In addition, culture-based evidence suggests that low iron availability can induce the production of highly recalcitrant DOM by Antarctic phytoplankton and thus that iron and DOM limitation could be synergistically limiting bacterial growth (Becquevort et al., 2007).

In this study, we sought to investigate several parameters relevant to the cycling of iron and vitamin $B_{12}$ in the southern Ross Sea. The results presented here indicate that availability of iron can regulate phytoplankton growth rates, impact bacterial growth, and influence $\mathrm{B}_{12}$ uptake rates during the austral spring.

\section{MATERIALS AND METHODS STUDY AREA AND WATER COLLECTION}

These experiments were conducted in the Ross Sea during the CORSACS 2 cruise in austral spring 2006 (NBP0608). Additional samples were collected during the CORSACS 1 cruise in the austral summer of 2005-2006 (NBP06081). For the bottle incubation experiments, water was collected from $\sim 3 \mathrm{~m}$ depth using a trace metal clean (TMC) Teflon diaphragm pumping system (Bruland et al., 2005; Sedwick et al., in review). All sample and incubation bottles used were detergent and acid-cleaned $[0.1 \%$ citranox for $48 \mathrm{~h}, 10 \% \mathrm{HCl}$ (Baker, Instra-analyzed) for 7 days, clean $\mathrm{pH} 2$ water (dilute $\mathrm{HCl}$ ) rinsed]. Sample bottles were filled and manipulated in a positive-pressure TMC environment constructed with laminar flow hoods and plastic sheeting to avoid trace metal contamination.

\section{SHIPBOARD BOTTLE INCUBATION STUDY}

A bottle incubation experiment using whole seawater with additions of $1 \mathrm{nM}$ added iron, $500 \mathrm{pM}$ added cobalt, $1 \mathrm{nM}$ added zinc, and $100 \mathrm{pM}$ added vitamin $\mathrm{B}_{12}$ was started in the Ross Sea on December 3, 2006 at $76.50^{\circ} \mathrm{S} 179.99^{\circ} \mathrm{W}$, hereafter referred to as Station SP3 (Figure 1), and carried out for 6 days. Whole seawater was dispensed into a $50 \mathrm{~L}$ TMC mixing carboy and from there into $2.2 \mathrm{~L}$ polycarbonate $(\mathrm{PC})$ bottles in triplicate for each treatment $\left(+\mathrm{Co},+\mathrm{Fe},+\mathrm{B}_{12},+\mathrm{Zn},+\mathrm{B}_{12} \mathrm{Fe},+\mathrm{CoFe}\right.$, $+\mathrm{ZnFe}$, and unamended control). The bottles were tightly capped and placed outdoors in deckboard flow-through incubators at $\sim 20 \%$ ambient light, shielded with neutral density screening. Ambient temperature $\left(-2\right.$ to $\left.1^{\circ} \mathrm{C}\right)$ was maintained by a constant flow of surface seawater through the incubators. Approximately every $60 \mathrm{~h}$, nutrients and chlorophyll $a(\mathrm{Chl} a)$ were measured. At the beginning and the end of the experiment, samples were taken for phytoplankton microscopy, pigment analysis, particulate organic carbon (POC) analysis, and bacterial cell counts.

\section{TRACE NUTRIENT SUPPLEMENTATION}

In all cases, iron was added as $\mathrm{FeCl}_{3}$ (Fluka), cobalt was added as $\mathrm{CoCl}_{2}$ (Fluka), and zinc was added as $\mathrm{ZnSO}_{4}$ (Fisher), all in weakly acidified ( $\mathrm{pH} \mathrm{3}$, SeaStar $\mathrm{HCl}$ ) Milli-Q water. Vitamin $\mathrm{B}_{12}$ (Sigma, Plant-cell culture tested cyanocobalamin, 99\%) was added as a solution in Milli-Q water, purified for trace metals by passing through a column of $2-3 \mathrm{~mL}$ of prepared Chelex-100 beads (BioRad; Price et al., 1988/1989).

\section{BACTERIAL REGROWTH EXPERIMENT}

A TMC bacterial regrowth experiment was conducted at station SP3 (Figure 1). Two liters of water, collected in a $2.5 \mathrm{~L}$ PC bottle as described above, was filtered using an acid-cleaned $0.2 \mu \mathrm{m}$ cartridge filter and supplemented with $10 \% 0.65 \mu \mathrm{m}$ filtered water, containing a portion of the free-living bacterial community from the same location (syringe filtered with an acid-cleaned PC filter membrane in an acid-cleaned $25 \mathrm{~mm}$ Swinnex filter holder). Triplicate aliquots of $250 \mathrm{~mL}$ each were removed into acid-cleaned polyethylene bottles as unamended controls. $1 \mathrm{nM} \mathrm{Fe}$ (as above) was added to the remaining mixture, and three aliquots of $250 \mathrm{~mL}$ each were removed into acid-cleaned polyethylene bottles for iron addition treatments. Sample aliquots $(27 \mathrm{~mL})$ were preserved with $10 \%$ filtered formalin and retained for bacterial cell enumeration. The experimental treatments were all incubated in the dark at $0^{\circ} \mathrm{C}$. After 3 days, $10 \mathrm{~mL}$ was removed from each treatment, preserved with $10 \%$ filtered formalin, and reserved for bacterial cell enumeration.

\section{NUTRIENT ANALYSIS}

Nutrients, including nitrate plus nitrite, nitrite, phosphate, and silicic acid were measured in the incubation experiments approximately every $60 \mathrm{~h}$, in $0.2 \mu \mathrm{m}$ filtered subsamples from each bottle in the bottle incubation study. Analysis was performed at sea using a Lachat QuickChem Autoanalyzer. Minimum detectable levels were $0.04 \mu \mathrm{M}$ phosphate, $0.09 \mu \mathrm{M}$ nitrate plus nitrite, $0.01 \mu \mathrm{M}$ nitrite, and $0.38 \mu \mathrm{M}$ silicic acid.

\section{BIOMASS ANALYSIS}

Over the course of the bottle incubation experiment, total Chl a was measured approximately every $60 \mathrm{~h}$ using $90 \%$ acetone extracts and the non-acidified fluorometric method (Welschmeyer, 1994), employing a Turner Designs TD700 fluorometer and Whatman GF/F filters. Bacteria were enumerated using a previously published method involving DAPI $\left(4^{\prime}-\right.$ 6-Diamidino-2-phenylindole) staining (Porter and Feig, 1980). Samples for phytoplankton community composition analysis were preserved with $1 \%$ glutaraldehyde, filtered on to $2 \mu \mathrm{m}$ pore size PC filters, and analyzed by using 2000 individual counts at $100 \times$ magnification via standard epifluorescence microscopy techniques coupled with DAPI staining. Obtaining accurate cell concentration estimates was not possible by our method due to the high abundance and extensive clumping of Phaeocystis cells, so these counts can only be used to assess community composition, not abundance. Phytoplankton pigment samples $(0.25-1 \mathrm{~L})$ were filtered on to Whatman $\mathrm{GF} / \mathrm{F}$ filters, flash frozen in liquid nitrogen, and stored at $-80^{\circ} \mathrm{C}$ prior to analysis by HPLC (Zapata et al., 2000; DiTullio and Geesey, 2002). Samples for POC analysis (100-200 mL) were filtered onto pre-combusted $\left(450^{\circ} \mathrm{C}, 2 \mathrm{~h}\right)$ Whatman $\mathrm{GF} / \mathrm{F}$ glass fiber filters, which were then analyzed using a Carlo Erba NA1500 elemental analyzer/Conflo II device and a Finnigan Delta Plus mass spectrometer at the Stanford University Stable Isotope Biogeochemistry Laboratory. Elemental compositions were measured using the mass 44 beam intensity (V) on the Delta Plus, calibrated against the mass 44 beam intensity of at least five certified reference standards that were analyzed throughout the course of each run 
of 40 samples. Relative reproducibility of the acetanilide standard averaged $0.65 \%$ for carbon.

\section{VITAMIN $B_{12}$ UPTAKE}

Measurement of short-term $B_{12}$ uptake using tracer level additions of the vitamin is difficult given the low picomolar concentrations of $B_{12}$ in natural waters (Menzel and Spaeth, 1962; Panzeca et al., 2009). For this reason, we chose to measure "potential uptake" rates with the addition of ${ }^{57} \mathrm{Co}$-labeled $\mathrm{B}_{12}(0.09 \mathrm{pM})$ and $40 \mathrm{pM}$ unlabeled $\mathrm{B}_{12}$. This measurement is practical in that it can allow for short-term rate assessments and does not require the measurement of water column vitamin concentrations. The measurements reflect rates of uptake at the specific concentration of the vitamin added and not in situ rates. As such, they are useful for comparing uptake rates between experimental treatments, but cannot be used to estimate the true rate of removal of $B_{12}$ from the water column by phytoplankton and bacteria.

${ }^{57}$ Co-labeled cyanocobalamin was used to measure the rate of vitamin $B_{12}$ uptake at the site of the bottle incubation study and in the community present at the end of the bottle incubation experiments, as well as at other sites within the Ross Sea. Uptake by the $>2$ and $>0.2-\mu \mathrm{m}$ size fractions was measured according to previously published protocols (Bertrand et al., 2007). Briefly, approximately $0.09 \mathrm{pM}^{57} \mathrm{Co} \mathrm{B}_{12}\left(360 \mu \mathrm{Ci} / \mathrm{g}^{57} \mathrm{Co} \mathrm{B}_{12}\right)$ and $40 \mathrm{pM}$ unlabeled vitamin $B_{12}$ were added to duplicate or triplicate $160 \mathrm{~mL}$ PC bottles filled with whole sea water from specific Ross Sea locations or with aliquots of whole incubation experiment water from the different incubation treatments described above. After $24 \mathrm{~h}$, the samples were filtered through 0.2 or $2 \mu \mathrm{m}$ PC filter membranes and rinsed with $1-2 \mathrm{~mL}$ of $0.4 \mu \mathrm{m}$ - filtered seawater each. The ${ }^{57} \mathrm{Co}$ radioactivity on each filter was determined using a Canberra Germanium Gamma detector. Since natural concentrations of vitamin $B_{12}$ in pristine environments are believed to lie in the low picomolar range (Menzel and Spaeth, 1962; Swift, 1981; Panzeca et al., 2009) and the ${ }^{57} \mathrm{Co}$-labeled $\mathrm{B}_{12}$ was added in sub-picomolar concentrations, the total concentration of $\mathrm{B}_{12}$ can be approximated as the amount of unlabeled $B_{12}$ added in these experiments $(\sim 40 \mathrm{pM})$. Using the percent uptake of radiolabeled $\mathrm{B}_{12}$ and this total concentration, total vitamin $B_{12}$ uptake per day was calculated for each filter size, as described by the equation $B_{12}$ uptake/L/day = counts of ${ }^{57} \mathrm{Co} \mathrm{B}_{12}$ on filter/L/day $\times 1 /$ counts of ${ }^{57} \mathrm{Co} \mathrm{B}_{12}$ added $\times$ total $\mathrm{B}_{12}$ concentration. The $0.2-\mu \mathrm{m}$ filter activity was considered indicative of total community uptake. The $2-\mu \mathrm{m}$ filter represented eukaryotic uptake from the $>2-\mu \mathrm{m}$ size fraction while the $0.2-\mu \mathrm{m}$ filter minus the $2-\mu \mathrm{m}$ filter was considered a proxy for the bacterial community uptake rate. Control studies were conducted at several locations during the CORSACS 1 cruise by killing the community with glutaraldehyde ( $1 \%$ final concentration, $B_{12}$ added $3 \mathrm{~h}$ after glutaraldehyde added) or with heat (microwaving a $180-\mathrm{mL}$ sample for $5 \mathrm{~min}$, shake, repeat three times; $\mathrm{B}_{12}$ added $3 \mathrm{~h}$ after heat-killed). Killed controls were incubated at $0^{\circ} \mathrm{C}$ in the dark. A titration experiment was conducted at station NX 14 (37 m depth, November $18,2006,75.93^{\circ} \mathrm{S}, 178.36^{\circ} \mathrm{E}$ ) where varying amounts of non-radiolabeled $B_{12}$ was added to whole seawater and $24 \mathrm{~h}$ uptake rate measurements were taken to determine how these added concentrations affected uptake rate by the $>2-\mu \mathrm{m}$ size fraction. In addition, a time course experiment with $40 \mathrm{pM}$ added $\mathrm{B}_{12}$ was conducted at station NX 17 (17 m depth, November 26, 2006; $\left.76.50^{\circ} \mathrm{S}, 178.55^{\circ} \mathrm{E}\right)$ to examine changes in uptake rate in the $>2-\mu \mathrm{m}$ size fraction between $10 \mathrm{~min}$ and $50 \mathrm{~h}$.

\section{STATISTICS}

Student's unpaired $t$-test was used to determine the statistical significance of differences between treatments. $T$ and $p$ values are reported and differences are discussed at the $95 \%$ confidence level.

\section{RESULTS AND DISCUSSION PHYTOPLANKTON AND BACTERIAL GROWTH LIMITATION BY IRON}

In the incubation experiment conducted at Station SP3, bottles of unfiltered surface seawater were supplemented in triplicate with iron, cobalt, zinc, and vitamin $\mathrm{B}_{12}$ (Figure 2). Iron addition increased Chl $a$ production as well as nitrate and phosphate drawdown relative to the unamended control treatments, suggesting that primary production in this area was limited by iron availability. Iron limitation of phytoplankton growth in the Ross Sea has previously been observed during summer, but not during spring (Martin et al., 1990; Sedwick et al., 2000; Coale et al., 2003). This finding represents the first evidence of iron limitation in the Ross Sea during the spring, and reflects the low surface dissolved iron concentration measured at station SP3 $(0.035 \mathrm{nM})$, which is considerably lower than previously reported springtime values for this region (Sedwick et al., 2000; Coale et al., 2005; Sedwick et al., in review). These observations require that the conceptual model of seasonal iron limitation in the Ross Sea, where iron becomes gradually depleted from wintertime maxima and phytoplankton populations become iron limited only in summer (e.g., Sedwick et al., 2000), be revised to allow that these waters may become iron limited relatively early in the growing season (Sedwick et al., in review). The observation of springtime iron limitation in this P. antarctica-dominated community also demonstrates that $P$. antarctica can be prone to iron limitation in Ross Sea natural communities despite low cellular iron requirements (Garcia et al., 2009; Sedwick et al., in review).

Silicic acid drawdown was negligible in all experimental treatments, suggesting that diatoms comprised only a minor portion of the community. This finding is supported by microscopydetermined phytoplankton community analyses (Table 1) and by pigment analyses (Figure 3). For all treatments, $P$. antarcticadominated the community at the beginning and end of the incubation experiment. However, based on the microscopy-determined community composition, both diatom and Phaeocystis abundance must have increased their growth rates comparably in response to iron addition since the diatoms remained an approximately constant proportion of the community throughout the experiment (Table 1). Likely because of their small initial abundance and thinly silicified nature (e.g., Pseudonitzschia spp.), diatom biomass remained relatively low and did not decrease in silicic acid concentrations despite an iron-induced increase in growth.

Figure 3 shows ratios of particulate 19-hexanolyoxyfucoxanthin (Hex), a haptophyte indicator pigment indicative of $P$. antarctica in the Ross Sea, to the pigment fucoxanthin (Fuco), which is primarily indicative of diatoms (DiTullio and Smith, 1996). Hex:Fuco ratios $>2$ indicate relative dominance of Phaeocystis; all samples 


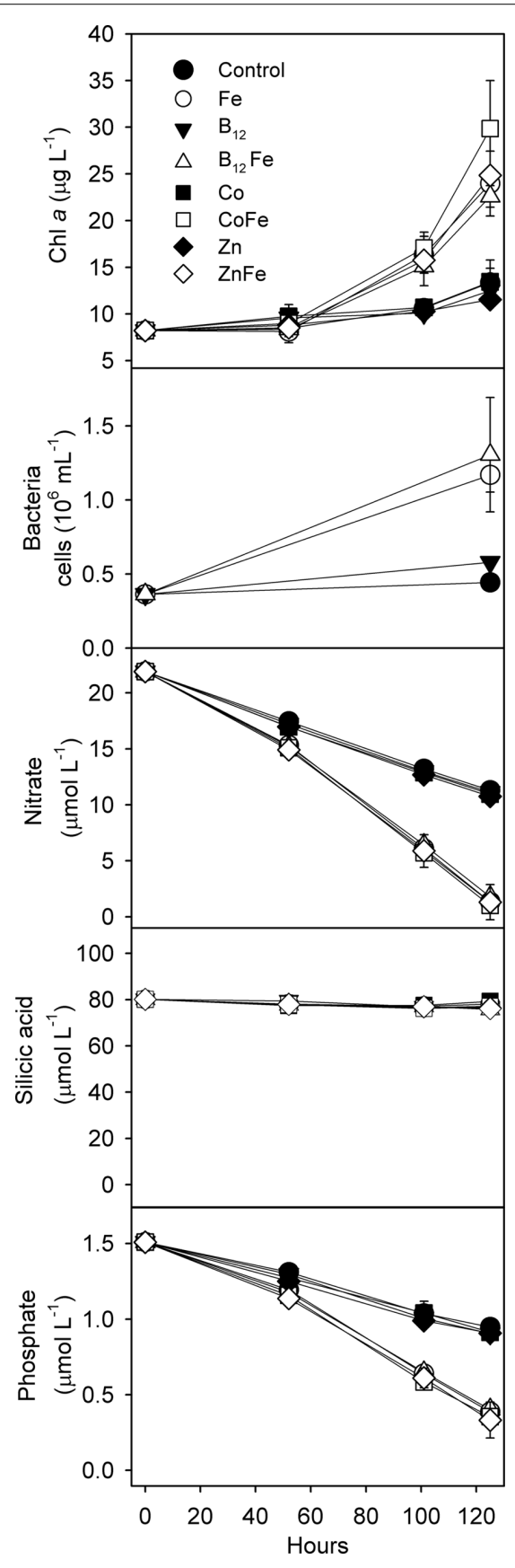

FIGURE 2 | Results of a trace metal clean whole-water bottle incubation experiment demonstrating that both phytoplankton and bacteria were iron limited. This experiment was conducted during the austral spring of 2006 at station SP3 in the Ross Sea; Chl a, bacterial cells, and major nutrient concentrations over time are shown. Values shown are means of triplicate treatments with error bars representing one SD. Where error bars are not visible, they fall within the bounds of the symbol. Iron stimulated enhanced $\mathrm{Chl}$ a production as well as major nutrient drawdown. No significant additional stimulation of $\mathrm{Chl}$ a production was observed upon the addition vitamin $B_{12}$ and iron, zinc and iron, or cobalt and iron, relative to iron alone, suggesting that neither $\mathrm{Co}, \mathrm{Zn}$ nor $\mathrm{B}_{12}$ was secondarily limiting phytoplankton growth. The addition of iron also, either directly or indirectly through increased availability of fixed organic nutrients, caused increased bacterial growth. from the incubation experiment had Hex:Fuco ratios $>4$, indicating strong haptophyte dominance. However, the iron-amended incubation samples had a $35 \pm 7 \%$ lower Hex:Fuco ratio than the unamended incubation treatments at the end of the experiment (Figure 3). The most likely explanation for this, given the absence of an increase in silicic acid drawdown that should accompany a significant increase in diatom growth, is that Phaeocystis increased its fucoxanthin production upon alleviation of iron limitation, as previously observed (Van Leeuwe and Stefels, 1998). The 1-nM iron additions used here have been shown to decrease Hex:Fuco production in Phaeocystis approximately 10fold (DiTullio et al., 2007). It is also possible that the growth of very thinly silicified diatoms were fueled by iron addition, which would not result in a significant silicic acid drawdown (Hutchins et al., 2001). However, the N/P drawdown ratios in both the ironamended $(\mathrm{N} / \mathrm{P}=18.0 \pm 0.4)$ and unamended $(\mathrm{N} / \mathrm{P}=18.4 \pm 0.4)$ treatments were similar (Figure 2). Since diatoms display a much lower N:P drawdown ratio than $P$. antarctica populations in the Ross Sea (diatoms: $9.7 \pm 0.3$; P. antarctica $19.2 \pm 0.6$; Arrigo et al., 1999, 2000), these measured ratios suggests that $P$. antarctica, rather than diatoms, were primarily responsible for nutrient drawdown regardless of iron nutritional status. Taken together, these community analyses suggest that dissolved iron availability was not an important factor in driving community structure in this experiment since $P$. antarctica and diatoms remained in approximately equal proportions throughout. The increase in Phaeocystis growth upon iron addition in this experiment is consistent with culture experiments that suggest iron half saturation constants for $P$. antarctica growth are well above the very low concentration of ambient dissolved iron $(0.035 \mathrm{nM})$ that was measured in seawater at station SP3 (Garcia et al., 2009; Saito et al., in preparation).

The paired additions of vitamin $\mathrm{B}_{12}$ with iron, zinc with iron, or cobalt with iron did not increase $\mathrm{Chl} a$ production or nutrient drawdown relative to the addition of iron alone or appreciably change Hex:Fuco ratios beyond those changes induced by iron. While these results initially appear to be in contrast to our previous observations of $\mathrm{B}_{12}$ and Fe colimitation of phytoplankton growth in the Ross Sea during summer (Bertrand et al., 2007), we believe that the results of these spring and summer experiments are consistent based on two observations. First, the initial bacterial abundance in this bottle incubation experiment was high $\left(3.6 \pm 0.05 \times 10^{5}\right.$ cells $\left.\mathrm{mL}^{-1}\right)$ relative to areas in the Ross Sea where strong vitamin $\mathrm{B}_{12}$ and iron colimitation was observed in the summer $\left(\sim 6 \times 10^{4}\right.$ cells $\left.\mathrm{mL}^{-1}\right)$, as illustrated in Figure 4. If bacteria are indeed the major source of $B_{12}$ in this system, then greater bacterial abundance during spring could result in greater availability of vitamin $B_{12}$. Second, our previous summer experiments showed that $\mathrm{B}_{12}$ addition did not stimulate the growth of $P$. antarctica, the dominant phytoplankter in this experiment. Although it is possible that $P$. antarctica does not require vitamin $\mathrm{B}_{12}$ for growth, the lack of a $P$. antarctica response might also reflect the high bacterial abundances associated with Phaeocystis colony mucilage (Putt et al., 1994), which may provide a localized source of $\mathrm{B}_{12}$. The lack of evidence for zinc or cobalt limitation or colimitation with iron in this experiment is also comparable with other Ross Sea studies where zinc additions increase $\mathrm{Chl} a$ production in some but not all locations (Cochlan et al., 2002; Coale et al., 2003) 
Table 1 | Phytoplankton community composition during the incubation experiment at station SP3, given as percentage of total individual cells in the community, in the initial community and at the end of the incubation in the control, and iron added treatments. For the initial community and the control treatment, only single counts were conducted. For the final timepoint in the + Fe treatment, single counts on triplicate bottles were performed; \pm 1 SD is shown.

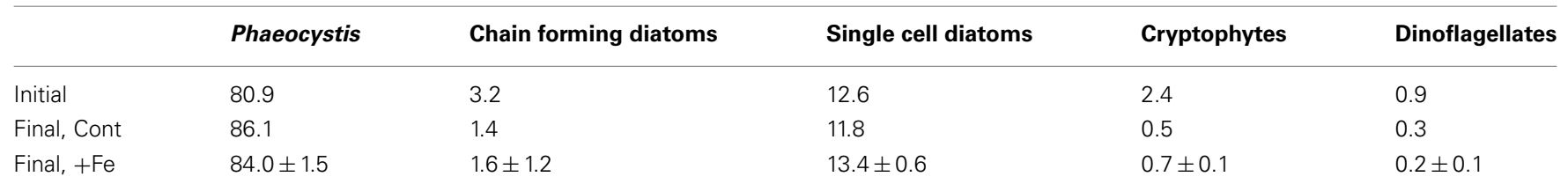

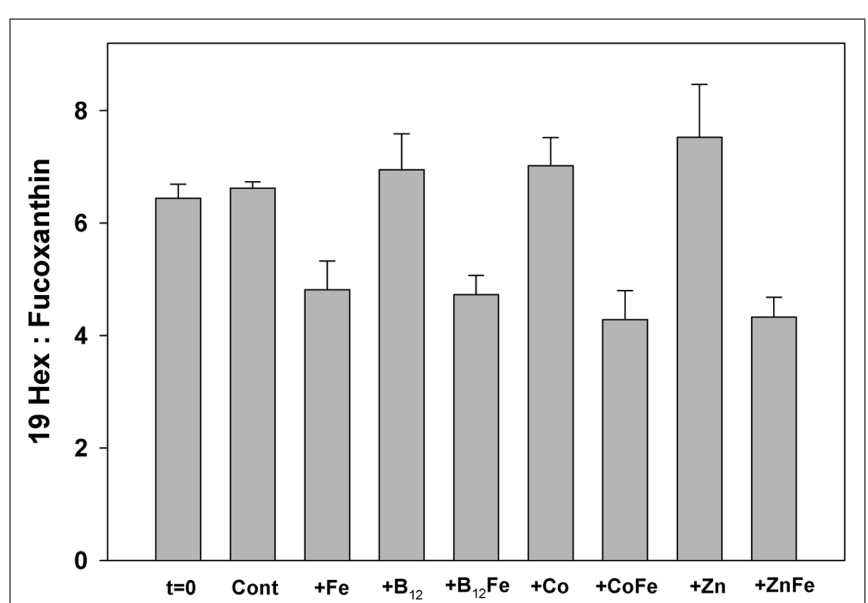

FIGURE 3 | Ratios of particulate 19-hexanolyoxyfucoxanthin (19-Hex) to fucoxanthin (Fuco), measured by HPLC analysis, at the beginning of the incubation experiment and at the end for each treatment. Bars are means of three biological replicates and error bars are one SD. In the Ross Sea 19-Hex predominantly represents Phaeocystis and Fuco predominantly represents diatoms. All samples throughout the experiment had ratios in excess of four, illustrating strong Phaeocystis dominance.

and cobalt additions did not increase $\mathrm{Chl} a$ production (Bertrand et al., 2007), all consistent with the high concentrations of labile Co in this region (Saito et al., 2010) and the interreplacement of cobalt and zinc in P. antarctica (Saito and Goepfert, 2008).

Iron additions also substantially increased bacterial abundance in our bottle incubation experiment $(\sim 3$-fold greater increase in bacterial abundance over 5 days in the + Fe treatment versus the control; Figure 2) indicating that bacterial growth was limited by iron, either directly, or through iron-induced changes in organic matter production by phytoplankton. While iron addition increased phytoplankton abundance and potentially organic matter production, iron additions might also have altered the composition of the organic matter since culture experiments have shown that high iron concentrations $(2 \mathrm{nM})$ substantially increase the lability of $P$. antarctica-derived organic matter (Becquevort et al., 2007).

In order to investigate whether bacterial communities were limited by iron availability directly or by the supply of organic matter from phytoplankton, an additional bacterial regrowth experiment was conducted in which grazers and phytoplankton were excluded by filtration ( $0.65 \mu \mathrm{m}$ pore size), and the remaining bacterial community was diluted and allowed to grow with and without $1 \mathrm{nM}$

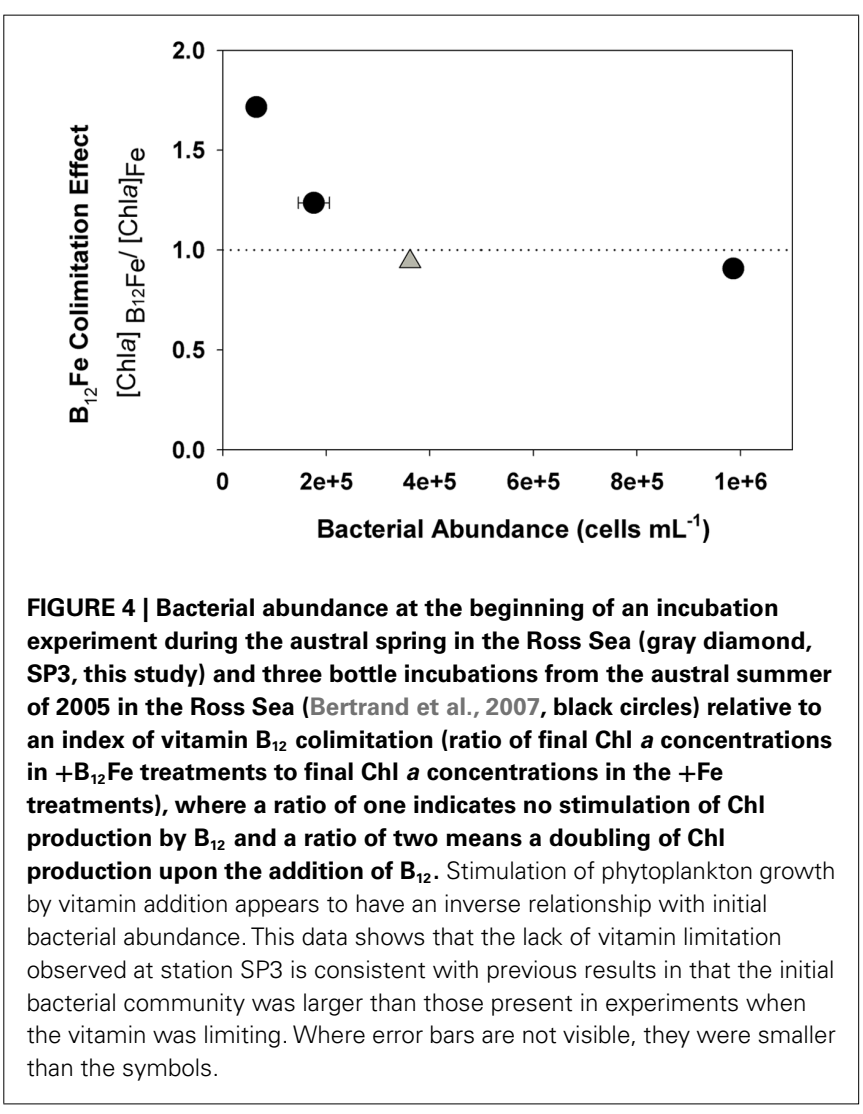

iron amendments. As shown in Figure 5, iron addition increased the cell-specific growth rate to $0.29 \pm 0.01$ day $^{-1}$ over a rate of $0.21 \pm 0.03 \mathrm{day}^{-1}$ in the unamended control treatment (error is one SD about the mean of biological triplicate measurements). The filtration employed to remove the grazing and phytoplankton community may have increased DOM concentration and changed DOM composition, but any such changes would have been uniform across the treatments. We thus conclude that dissolved iron addition directly enhanced bacterial growth rates in this assemblage and that bacterial growth rates in these waters may be subject to colimitation by the availability of DOM and iron. While these growth rates are within the range of previously reported values for the Ross Sea (0.25 day ${ }^{-1}$; Ducklow, 2000), they may deviate from in situ rates due to sample manipulation involved in the experiment. These results suggest that iron availability directly impacts bacterial growth rates in the Ross Sea and highlight that bacteria compete with phytoplankton for dissolved iron. 


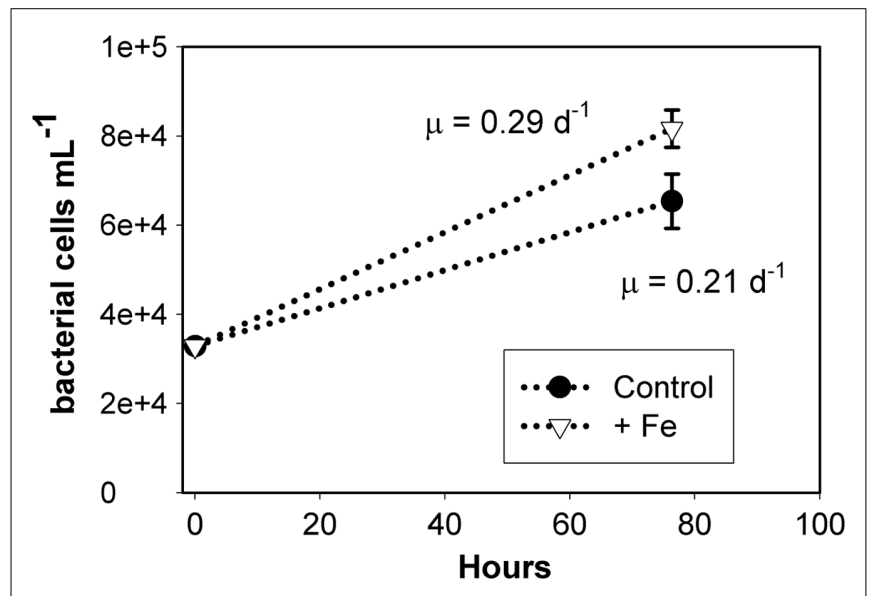

FIGURE 5 | Results from a bacterial regrowth experiment at station SP3, demonstrating that iron directly impacted bacterial growth rates. Bacterial and archaeal abundance (cells per milliliter) over time for the iron added and unamended control are shown, with error bars representing SD of single counts from triplicate incubations. The cell-specific growth rates (shown in figure) in these two treatments are significantly different $(T=3.8$, $p=0.03$ ), suggesting that bacterial growth rate is directly iron limited.

\section{VITAMIN B ${ }_{12}$ UPTAKE: IRON INFLUENCES AND BACTERIAL CONTRIBUTION}

Uptake of $\mathrm{B}_{12}$ by biota is considered a major sink for the vitamin in natural waters (Karl, 2002). In this study, we used radiotracer additions to examine the effect of iron amendments on vitamin $B_{12}$ uptake rates by microbial communities in the incubation experiment described above and in several proximal locations. Heat and glutaraldehyde-killed treatments verified that this measured $B_{12}$ uptake occurred through active rather than passive mechanisms (Figure 6), thus reflecting biological processes rather than adhesion to particulate matter. The technique used to measure these rates involved the addition of large amounts of vitamin $\mathrm{B}_{12}(\sim 40 \mathrm{pM})$. This non-tracer level addition was chosen to facilitate a comparison of uptake rates between experimental treatments without the need for measuring ambient vitamin $B_{12}$ concentrations in this small-volume incubation experiment. Since calculated $B_{12}$ uptake $=$ fraction of tracer taken up $\times$ total vitamin concentration, these $\sim 40$ pM additions significantly increased the calculated uptake rates compared ambient $\mathrm{B}_{12}$ concentrations (Figure 7A). These calculated rates thus do not represent in situ uptake, but rather rates at this relatively high $\mathrm{B}_{12}$ concentration.

Typical models for nutrient uptake predict that progressive additions of higher nutrient concentrations increase nutrient uptake rates until the community's uptake machinery is saturated. Interestingly, the $\sim 40 \mathrm{pM} \mathrm{B}_{12}$ additions used here did not saturate phytoplankton community uptake rates (Figure 7A), and even up to $95 \mathrm{pM}$ of added $\mathrm{B}_{12}$ did not appear to saturate these rates. If we assume a Michaelis-Menten type kinetic relationship between uptake rate and added vitamin concentrations, plotting the data in Figure 7A in double reciprocal form (data not shown) yields a half saturation constant of $83 \mathrm{pM}$ for $\mathrm{B}_{12}$ uptake, which is much higher than typical ambient $\mathrm{B}_{12}$ concentrations.

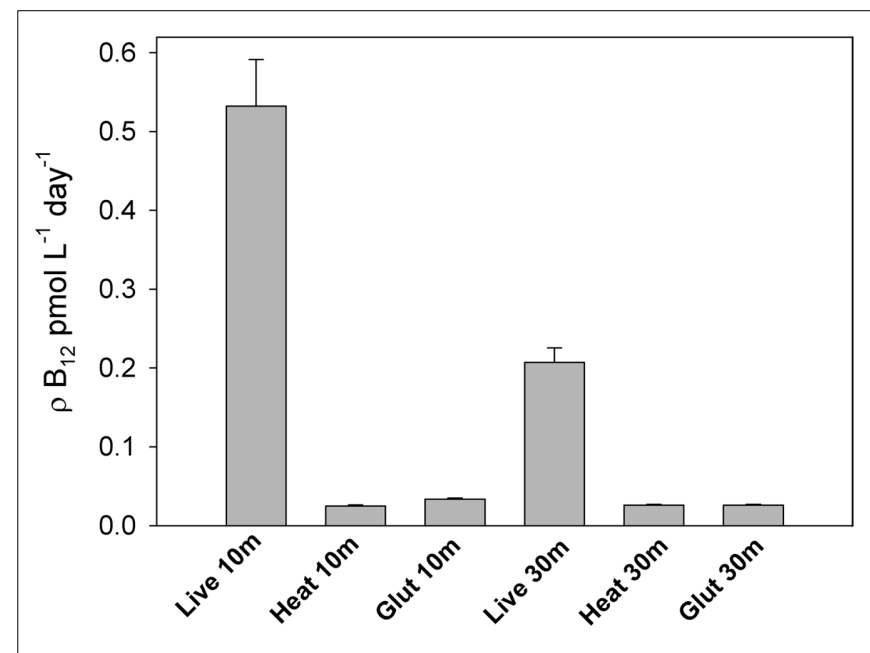

FIGURE 6 | Vitamin $B_{12}$ uptake rates in live samples and killed controls, demonstrating that the method employed here to measure $B_{12}$ uptake is not significantly impacted by non-specific adhesion of $B_{12}$ to particulate matter and primarily measures active uptake. These data demonstrate that a filtered seawater wash is sufficient for removing most non-living particle and surface-associated vitamin $B_{12}$ from filters. This experiment was conducted in the Ross Sea at station NX $8\left(77.30^{\circ} \mathrm{S}\right.$, $175.44 \mathrm{~W}$ ) in the austral summer of 2005 . Triplicate $B_{12}$ uptake rates were measured in live samples; bars represent means and error bars show one $\mathrm{SD}$. Single killed controls per depth were conducted by killing the community with glutaraldehyde or heat. Error bars on the killed samples represent $5 \%$ counting error.

The technique we have applied can be used to compare calculated uptake rates in different experimental treatments assuming that the composition of the community in each experimental treatment does not appreciably change as a result of adding high $\mathrm{B}_{12}$ concentrations over the course of the $24-\mathrm{h}$ measurement. This assumption is supported by the observation that the uptake rates measured between 12 and $52 \mathrm{~h}$ were the same (Figure 7B) since $12 \mathrm{~h}$ is not enough time for a community composition change to occur given the typical generation times in polar waters. Interestingly, the uptake rate measured after 13 min was much faster than at the later timepoints, which is consistent with an uptake model whereby cell surface $B_{12}$-binding proteins are quickly saturated by the high concentrations of added $\mathrm{B}_{12}$, then, in a second slower step, the vitamin is transferred into the cell. This is analogous to experimental results showing that the rate of zinc uptake by diatoms was elevated in the first few minutes after the addition of high $\mathrm{Zn}$ concentrations, which was attributed to $\mathrm{Zn}$ binding to cell surface sites (Sunda and Huntsman, 1992) and is also consistent with results from $\mathrm{B}_{12}$ uptake studies in Ochromonas cultures showing that vitamin uptake also occurs sequentially, first rapidly and then a second slower phase (Bradbeer, 1971). The slight depression in $\mathrm{B}_{12}$ uptake rate between the 3 and 12-h timepoints (Figure 7B) is consistent with cells experiencing minor negative feedback in uptake rates after $>3 \mathrm{~h}$ of exposure to high $\mathrm{B}_{12}$ concentrations, as previously observed for other micro and macronutrients (Sunda and Huntsman, 1992).

There are few studies of $\mathrm{B}_{12}$ uptake rates in natural phytoplankton communities to date (Bertrand et al., 2007; Taylor and 


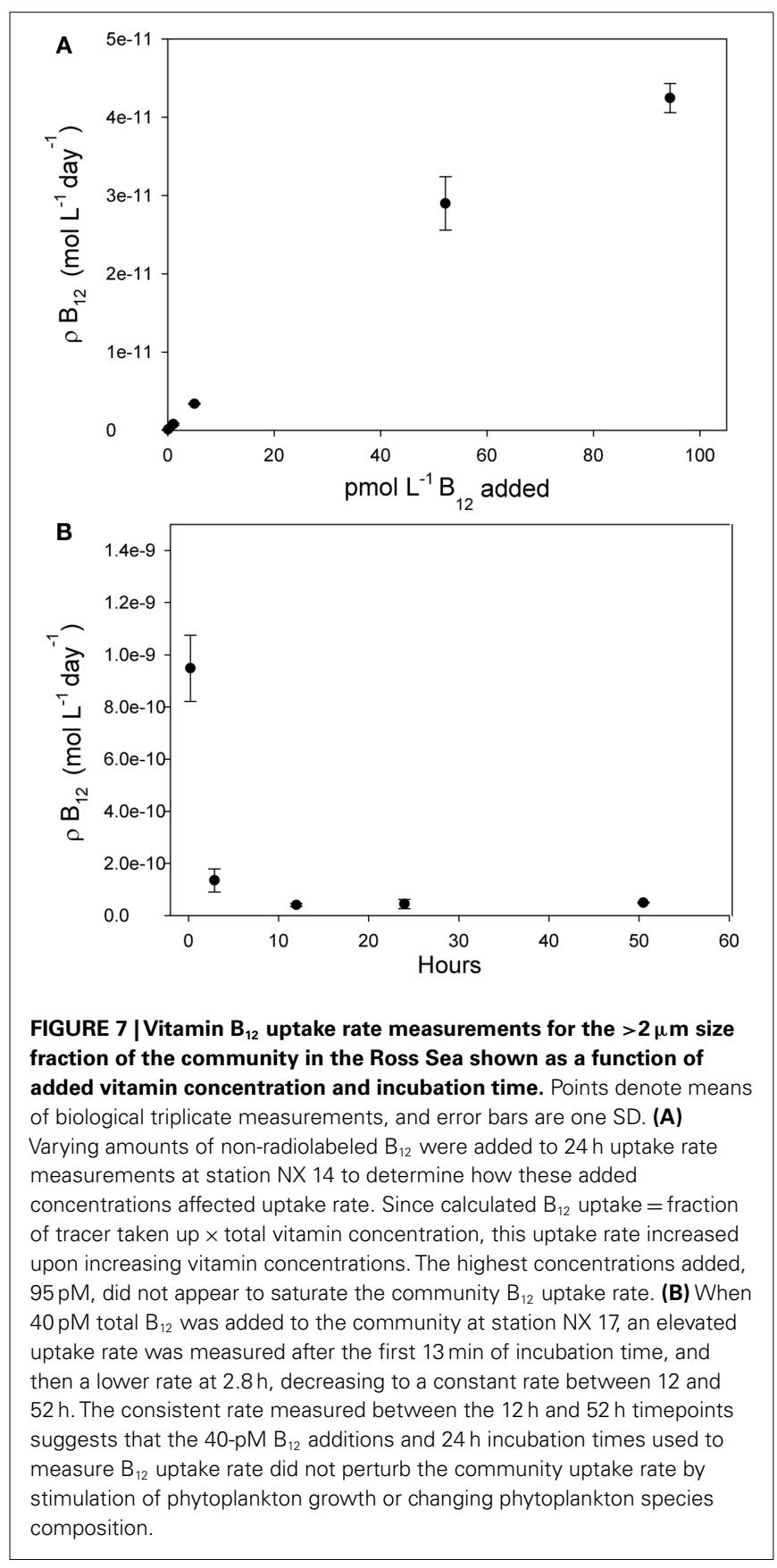

Sullivan, 2008; Koch et al., 2011). Such measurements are in early stages of development. Even in laboratory-based culture studies, measurements of $\mathrm{B}_{12}$ uptake are complex and have yielded results that are not easy to interpret (Droop, 1968). Measurements presented here offer an initial look at controls on $\mathrm{B}_{12}$ uptake in field populations, but further study is required to develop methodology for measuring in situ rates and to better constrain factors affecting cellular $\mathrm{B}_{12}$ uptake machinery.

\section{Phytoplankton size fraction $B_{12}$ uptake}

$B_{12}$ uptake was measured for two separate size fractions of the community, $0.2-2$ and $>2 \mu \mathrm{m}$. The $0.2-2-\mu \mathrm{m}$ size fraction includes largely non-photosynthetic bacteria and archaea since there are no appreciable cyanobacterial populations in the Ross Sea (Caron et al., 2000; Marchant, 2005) and picoplanktonic phytoplankton were not observed by our microscopy methods. The $>2-\mu \mathrm{m}$ size fraction includes eukaryotic phytoplankton, which comprise the vast majority of photosynthetic biomass in this region (Scott and Marchant, 2005).

At the end of the incubation experiment, the iron-amended treatment exhibited a substantially higher $\mathrm{B}_{12}$ uptake rate in the phytoplankton size fraction relative to the control (Figure 8). When normalized to $\mathrm{Chl} a$, this uptake rate was still higher in the iron-amended treatment than in the control at the final timepoint (significantly different; $T=7.99, p=0.015$, Figure 9A). This normalized value is a measure of how community vitamin uptake rates change relative to $\mathrm{Chl} a$ changes. It is unlikely that this increase in chlorophyll-normalized $\mathrm{B}_{12}$ uptake rate is solely a function of differences in cellular pigment concentration between treatments. This is because cells in the iron-amended treatment might be expected to contain more Chl $a$ per cell, since Chl deficiency (chlorosis) is often associated with iron limitation (Zettler et al., 1996). If a Chl-deficient cell (i.e., in the control treatment) had the same cell-specific $\mathrm{B}_{12}$ uptake rate as a Chlreplete cell (i.e., in the $+\mathrm{Fe}$ treatment), then the $\mathrm{Chl} a$-normalized $\mathrm{B}_{12}$ uptake rate should be higher in the control treatment. In fact, we observed the opposite trend: Chl-normalized $\mathrm{B}_{12}$ uptake rate was greater for the Fe-amended treatments, suggesting that this trend reflects an increase in community $\mathrm{B}_{12}$ uptake rate rather than changes in pigment composition. This result suggests that vitamin $B_{12}$ uptake by the phytoplankton community increased after iron addition due to (1) a change in species composition, (2) an increase in cellular vitamin transporters, or (3) an increased use of energy allocated to active vitamin transport systems in order to increase vitamin uptake rates in step with growth rates. The first scenario is unlikely, given that the community remained heavily dominated by $P$. antarctica in all treatments (Table 1, Figure 3), suggesting that the latter two mechanisms may be important.

In addition to revealing an effect of iron on $\mathrm{B}_{12}$ uptake, our experiment showed a $4-6 \times$ lower $\mathrm{Chl} a$-normalized $\mathrm{B}_{12}$ uptake rate at the beginning of the incubation experiment relative to the final timepoint, in both the control and iron-amended treatments (Figure 9A). Although both the initial and final uptake measurements were conducted under identical conditions in the deckboard incubator, the initial timepoint measurement was taken immediately upon transfer from in situ conditions to the shaded incubator while the final timepoint measurements were taken after a 5-day acclimation inside the bottle incubation experiment. Thus, the large change in uptake rate might partly reflect "bottle effects," or the impact of altered irradiance. If the conditions favored faster growth in the final stages of the experiment, then these enhanced uptake rates could reflect increased growth rate and overall energy available to cells, resulting in an increase in energy allocated to active vitamin transport systems that is unconnected to vitamin nutritional status. However, an increase in available energy at the end of the incubation experiment is unlikely, particularly in the case of the control treatment, since that community was becoming increasingly iron limited. These higher uptake rates may thus in 


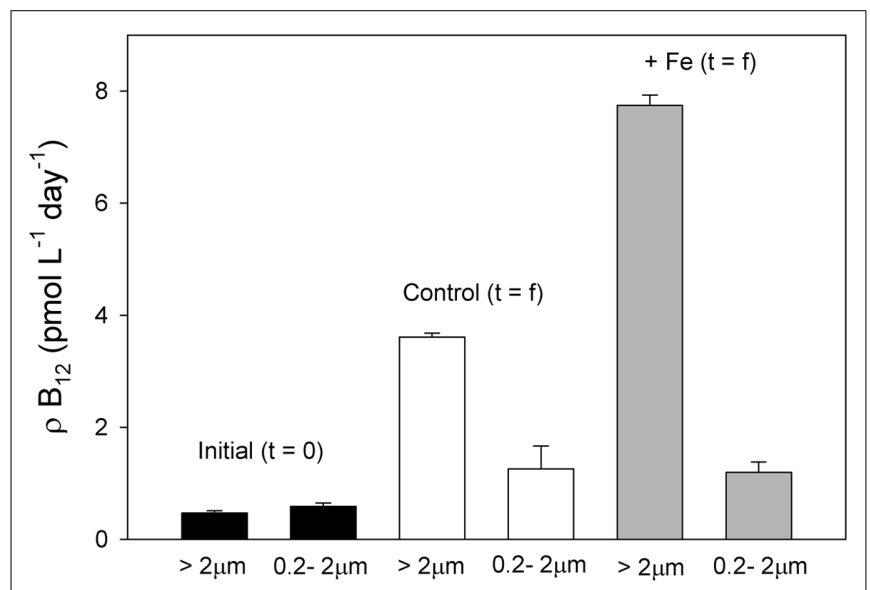

FIGURE 8 | Vitamin $B_{12}$ uptake rates in both the bacterial $(0.2-2 \mu \mathrm{m})$ and phytoplankton $(>2 \mu \mathrm{m})$ size fractions at initial and final timepoints in the bottle incubation experiment. While uptake rates increased by the final timepoint in all cases, the uptake rate for the phytoplankton size fraction but not the bacterial size fraction increased more in the iron added treatment. Rates at the final time point were measured from duplicate samples taken from a single replicate of the control (white bars) and Fe added treatments (gray bars). Means of triplicate initial $B_{12}$ uptake measurements are all shown with error bars representing one SD.

part reflect stress experienced by the phytoplankton due to depletion of available vitamin supplies. Although there is an internal source of vitamin $\mathrm{B}_{12}$ in these incubations (bacterial growth), the vitamin sinks due to bacterial and phytoplankton uptake and photochemical degradation (Carlucci et al., 1969) are likely to be considerable. On balance, this may result in progressive depletion of $\mathrm{B}_{12}$, mirroring the nitrate and phosphate drawdown observed in this experiment (Figure 2). Such depletion could induce an upregulation of vitamin transporters, which would be reflected in elevated $\mathrm{B}_{12}$ uptake rates.

The observed changes in $\mathrm{B}_{12}$ uptake rate are consistent with the phytoplankton communities becoming stressed for lack of this vitamin by the end of the incubation experiment, which would result in increased calculated uptake rates. However, the bottle incubation study did not show an increase in phytoplankton biomass upon vitamin $B_{12}$ addition, leading to the conclusion that there was no colimitation by vitamin $\mathrm{B}_{12}$ and iron at this time and location. This observation suggests that bottle incubations may not be sensitive to some subtle physiological states of nutrient stress that are nonetheless relevant for biogeochemical cycling and that might indicate susceptibility to nutrient limitation. Nutrient uptake studies like these, as well as the application of protein or transcript-based biomarker assays for gene products that are abundant under defined states of nutrient stress (LaRoche et al., 1996; Webb et al., 2001; Dyhrman et al., 2002), can complement bottle incubation studies and provide more subtle information about the limitation and colimitation experienced by microbial communities. The dramatic increase in vitamin uptake rates from the beginning to end of this incubation experiment and upon increasing $B_{12}$ concentrations (Figure 7) suggest that phytoplankton can exert considerable control over the cellular machinery that is used to take up vitamin $B_{12}$. This implies that future studies to

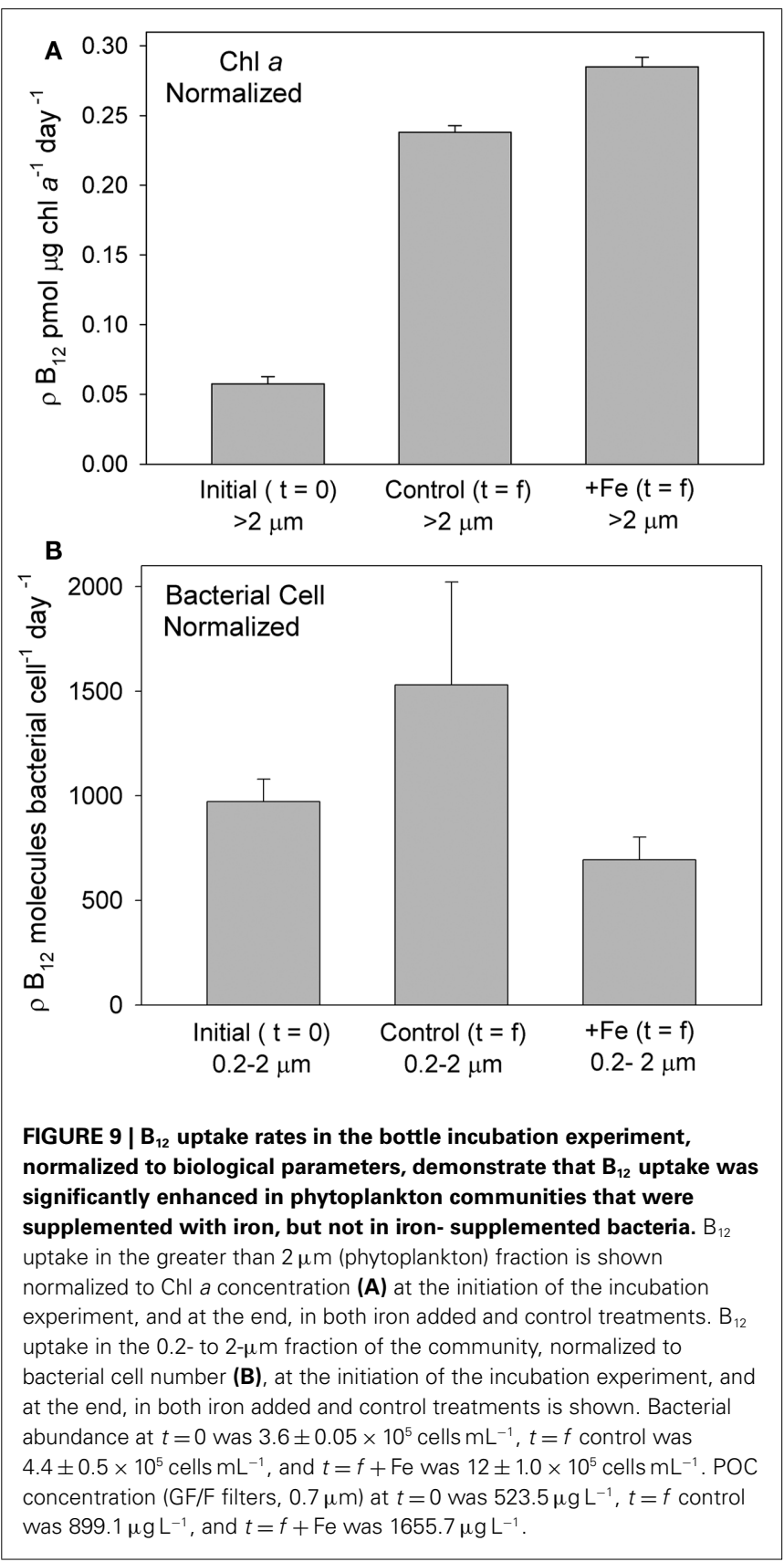

document the cellular response of phytoplankton to vitamin stress and to develop protein or transcript-based biomarkers for vitamin limitation may be feasible.

\section{Bacterial size fraction uptake}

The initial $\mathrm{B}_{12}$ uptake rates at the beginning of the incubation experiment were slightly greater for the $0.2-2-\mu \mathrm{m}$ size fraction than for the greater than $2 \mu \mathrm{m}$ fraction (Figure 8, not significantly different; $T=2.34, p=0.078$ ). This observation suggests that in addition to being the source of vitamin $\mathrm{B}_{12}$, the bacterial and archaeal community size fraction is also an important sink. This evidence, along with that offered in another study (Koch et al., 2011) favors a departure from the Karl (2002) model of vitamin 
$\mathrm{B}_{12}$ cycling, which suggests that eukaryotes dominate $\mathrm{B}_{12}$ uptake. Our results are also consistent with the fact that, according to currently available genomic sequencing information, many Antarctic marine bacterial strains appear to require an exogenous source of $\mathrm{B}_{12}$ (Bertrand et al., 2011).

The rate of $\mathrm{B}_{12}$ uptake by the $0.2-2-\mu \mathrm{m}$ size fraction normalized to the size of the bacterial community at the initial and final timepoints for the iron-amended treatment were not significantly different $(T=1.19, p=0.41)$, while uptake rates in the initial versus final community in the control treatment were significantly different $(T=3.44, p=0.04)$, with a higher $\mathrm{B}_{12}$ uptake rate in the final community (Figure 9B). Since many bacterial cells, including the abundant SAR11 clade, do not take up vitamin $B_{12}$ (Zhang et al., 2009), these rate measurements that are normalized to total cell abundance should not be taken as reflections of individual cell uptake rates but rather as a measure of the change in vitamin uptake rate relative to the change in bacterial community size. Although our experimental uncertainties are substantial, this trend may suggest a shift in community composition in the control treatment (under iron limitation) toward bacteria that take up exogenous $\mathrm{B}_{12}$, or enhanced cellular $\mathrm{B}_{12}$ uptake rate within that community. A similar shift or increase in uptake rate does not seem to have occurred in the iron replete treatments. This suggests that when iron availability is low, vitamin $B_{12}$ uptake by bacteria may increase. This hypothesis is consistent with reports that part of bacterial $\mathrm{B}_{12}$ demand arises from use in ribonucleotide reductase (RNR) enzymes, which use either iron or vitamin $\mathrm{B}_{12}$ and that, in some bacteria, the transcription of the gene encoding the ironrequiring $\mathrm{RNR}$ is only expressed when the $\mathrm{B}_{12}$ cell quotas are low (Borovok et al., 2006).

\section{IMPLICATIONS}

\section{Iron influences on $B_{12}$ production}

The results of our incubation and regrowth experiments suggest that dissolved iron availability can help regulate net bacterial productivity in the Ross Sea. Since vitamin $\mathrm{B}_{12}$ production rates are tied to bacterial productivity, our results further suggest that vitamin $B_{12}$ production could be influenced by the availability of dissolved iron. Although there are likely many factors contributing to $B_{12}$ production rates, vitamin availability to phytoplankton appears to scale with bacterial abundance since small bacterial communities were observed where $\mathrm{B}_{12}$ limited primary production (Figure 4). Constraining the rate of $\mathrm{B}_{12}$ production and the factors that regulate it presents challenges similar to those involved constraining the cycling of other trace level nutrients, such as ammonia. Knowing the concentration of vitamin $\mathrm{B}_{12}$ may not tell us much about its production rate, given its rapid uptake by the biota and its short photochemical half life in the surface ocean (Carlucci et al., 1969). Since the rate at which individual organisms conduct vitamin biosynthesis may be variable, knowing the number of community members that can produce the vitamin an an one time may also tell us little about the gross $\mathrm{B}_{12}$ production rate (Roling, 2007). The rate of vitamin transfer from the particulate to the dissolved pool, and not simply the rate of biosynthesis, must also be considered. This flux will be a function of the production rate within the local microbial communities; the rate of population turnover by grazing, viral lysis, and other factors, as well as the efficiency of the microbial loop. The addition of the vitamin due to mixing with other water masses is likely small (Panzeca et al., 2009), but must also be considered. These issues are beyond the scope of this paper, but are important for understanding the biogeochemistry of vitamin $\mathrm{B}_{12}$.

\section{Persistence and timing of phytoplankton and bacterial blooms in iron fertilization events}

The results of this study suggest that DOM consumption rates, insofar as they are related to bacterial growth, may be directly influenced by dissolved iron availability, and that $\mathrm{B}_{12}$ production and consumption in the Ross Sea are also likely impacted by iron. When taken together, these results present the possibility that during a natural or engineered iron fertilization event, $B_{12}$ production may increase and bacterial $B_{12}$ demand may decrease, thereby resulting in enhanced availability of $\mathrm{B}_{12}$ to phytoplankton. It is possible that this enhanced availability could alleviate $B_{12}$ colimitation of phytoplankton communities, resulting in increased primary production. However, the relative timing of these responses will determine the impact of synergistic vitamin and iron dynamics on ironinduced blooms. If the bacterial response to iron addition lags the phytoplankton response (more likely if the bacterial community is DOM limited), then the phytoplankton community is less likely to receive increased $B_{12}$ supply to meet its enhanced $B_{12}$ demand (Figure 7). This is likely to have occurred in the summertime Ross Sea experiments that observed $\mathrm{B}_{12}$ stimulation (Bertrand et al., 2007). However, if the bacterial response to dissolved iron addition is concurrent with the phytoplankton response (more likely if bacteria are primarily iron limited), then bacterial vitamin $\mathrm{B}_{12}$ production may keep pace with the increasing phytoplankton demand, preventing secondary vitamin $\mathrm{B}_{12}$ limitation. The balance between enhanced DOM consumption and altered vitamin $\mathrm{B}_{12}$ dynamics should be considered when evaluating the impact of bacterial communities during iron fertilization.

\section{CONCLUSION}

This study provides direct evidence of iron limitation of phytoplankton growth in the Ross Sea during spring, thus challenging the idea that this Antarctic shelf ecosystem is iron replete in the early growing season. In addition, bacterial growth in this location was shown to be directly iron limited or colimited by iron and DOM. These results imply that iron availability may limit vitamin $\mathrm{B}_{12}$ production, since bacteria and archaea are the only known source of $\mathrm{B}_{12}$ production in the water column. The bacterial size fraction of the microbial community also comprised a significant sink of vitamin $B_{12}$ in the water column, with uptake measurements suggesting that this sink may be reduced under iron replete conditions. Despite a lack of enhanced Chl production upon vitamin $B_{12}$ addition to the bottle incubation study here, vitamin $B_{12}$ uptake rate measurements suggest that phytoplankton may have experienced stress due to $B_{12}$ deficiency, particularly when iron limitation was alleviated.

\section{ACKNOWLEDGMENTS}

We thank David Hutchins for access to his laboratory van and for helpful discussions. Thanks to Julie Rose for training in phytoplankton identification, bacterial enumeration and helpful discussions, and to Ben Van Mooy for suggestions on bacterial regrowth studies and comments on the manuscript. 
We are grateful to Daniel Repeta, Phoebe Lam, Dawn Moran and Abigail Noble for comments on the manuscript. Thanks also to Bettina Sohst and Giulio Catalano for nutrient analyses and to Tyler Goepfert for help in incubation setup and sample processing. Special thanks to the Captain, Crew, and Raytheon Marine and Science Technical Staff of the RVIB N. B. Palmer and the CORSACS science parties. This research

\section{REFERENCES}

Armand, L. K., Crosta, X., Romero, O., and Pichon, J.-J. (2005). The biogeography of major diatom taxa in Southern Ocean sediments: 1. Sea ice related species. Palaeogeogr. Palaeoclimatol. Palaeoecol. 223, 93-126.

Arrigo, K. R., DiTullio, G. R., Dunbar, R. B., Robinson, D. H., VanWoert, M., Worthen, D. L., and Lizotte, M. P. (2000). Phytoplankton taxonomic variability in nutrient utilization and primary production in the Ross Sea. J. Geophys. Res. 105, 8827-8846.

Arrigo, K. R., Robinson, D. H., Worthen, D. L., Dunbar, R. B., DiTullio, G. R., VanWoert, M., and Lizotte, M. P. (1999). Phytoplankton community structure and the drawdown of nutrients and $\mathrm{CO} 2$ in the Southern Ocean. Science 283, 365-367.

Arrigo, K. R., van Dijken, G., and Long, M. (2008). Coastal Southern Ocean: a strong anthropogenic CO2 sink. Geophys. Res. Lett. 35, 6.

Becquevort, S., Lancelot, C., and Schoemann, V. (2007). The role of iron in the bacterial degradation of organic matter derived from Phaeocystis antarctica. Biogeochemistry 83, 119-135.

Bertrand, E. M., Saito, M. A., Jeon, Y. J., and Neilan, B. A. (2011). Vitamin B12 biosynthesis gene diversity in the Ross Sea: the identification of a new group of putative polar B12biosynthesizers. Environ. Microbiol. 13, 1285-1298.

Bertrand, E. M., Saito, M. A., Rose, J. M., Riesselman, C. R., Lohan, M. C., and Noble, A. E., Lee Peter, A., and Ditullio Giacomo, R. (2007). Vitamin B12 and iron co-limitation of phytoplankton growth in the Ross Sea. Limnol. Oceanogr. 52. 1079-11093.

Bonnet, S., Webb, E. A., Panzeca, C., Karl, D. M., Capone, D. G., and Sanudo-Wilhelmy, S. A. (2010). Vitamin B12 excretion by cultures of the marine cyanobacteria Crocosphaera and Synechococcus. Limnol. Oceanogr. 55, 1959-1964.

Borovok, I., Gorovitz, B., Schreiber, R., Aharonowitz, Y., and Cohen, G. (2006). Coenzyme B12 controls transcription of the Streptomyces class Ia ribonucleotide reductase $n r d A B S$ operon via a riboswitch mechanism. J. Bacteriol. 118, 2512-2520.

Bradbeer, C. (1971). Transport of vitamin B12 in Ochromonas malhamensis. Arch. Biochem. Biophys. 144, 184 192.

Bruland, K. W., Rue, E. L., Smith, G. J., and DiTullio, G. R. (2005). Iron, macronutrients and diatom blooms and blue waters of Peru. Mar. Chem. 93, 81-103.

Carlucci, A. F., Silbernagel, S. B., and McNally, P. M. (1969). The influence of temperature and solar radiation on persistence of vitamin B12, thiamine, and biotin in seawater. $J$.

Caron, D. A., Dennett, M. A., Lonsdale, D. J., Moran, D. M., and Shalapyonok, L. (2000). Microzooplankton herbivory in the Ross Sea, Antarctica. Deep Sea Res. II 47, 3249-3272.

Church, M. J., Hutchins, D. A., and Ducklow, H. W. (2000). Limitation of bacterial growth by dissolved organic matter and iron in the Southern Ocean. Appl. Environ. Microbiol. 66, 455-466.

Coale, K. H., Gordon, R. M., and Wang, X. (2005). The distribution and behavior of dissolved and particulate iron and zinc in the Ross Sea and Antarctic circumpolar current along $170^{\circ} \mathrm{W}$. Deep Sea Res. I 52, 295-318.

Coale, K. H., Wang, X., Tanner, S. J., and Johnson, K. S. (2003). Phytoplankton growth and biological response to iron and zinc addition in the Ross Sea and Antarctic circumpolar current along 170W. Deep Sea Res. II 50, 635-653.

Cochlan, W. P., Bronk, D. A., and Coale, K. H. (2002). Trace metals and nitrogenous nutrition of Antarctic phytoplankton: experimental observations in the Ross Sea. Deep Sea Res. II 49, 3365-3390.

Croft, M. T., Lawrence, A. D., RauxDeery, E., Warren, M. J., and Smith, A. G. (2005). Algae acquire vitationship with bacteria. Nature 438, 90-93.

DiTullio, G. R., Garcia, N., Riseman, S. F., and Sedwick, P. N. (2007). Effects of iron concentration on pigment in the Peru upwelling regime: brown Phycol. 5, 302-305. min B12 through a symbiotic rela-

was supported by NSF grants OCE-0752291, OPP-0440840, OPP-0338097, OPP-0338164, ANT-0732665, OCE-0452883, and OCE-1031271, the Center for Microbial Oceanography Research and Education (CMORE) and a National Science Foundation (NSF) Graduate Research Fellowship (2007037200) and an Environmental Protection Agency STAR Fellowship to EMB (F6E20324).

composition in Phaeocystis antarctica grown at low irradiance. Biogeochemistry 83, 71-81.

DiTullio, G. R., and Geesey, M. E. (2002). "Photosynthetic pigments in marine algae and bacteria," in The Encyclopedia of Environmental Microbiology, ed. G. Bitton (New York, NY: John Wiley and Sons, Inc.), 2453-2470.

DiTullio, G. R., and Smith, W. O. (1995). Relationship between dimethylsulfide and phytoplankton pigment concentrations in the Ross Sea, Antarctic. Deep Sea Res. II 42, 873-892.

DiTullio, G. R., and Smith, W. O. (1996) Spatial patterns in phytoplankton biomass and pigment distributions in the Ross Sea. J. Geophys. Res. 101, 18467-18478.

Droop, M. R. (1968). Vitamin B12 and marine ecology. IV. The kinetics of uptake, growth and inhibition in Monochrysis lutheri. J. Mar. Biol. Assoc. U.K. 48, 689-733.

Droop, M. R. (2007). Vitamins, phytoplankton and bacteria: symbiosis or scavenging? J. Plankton Res. 29 , 107-113.

Ducklow, H. (2000). "Bacterial production and biomass in the oceans," in Microbial Ecology of the Oceans, ed. D. Kirchman (New York, NY: Wiley Liss), 85-120.

Ducklow, H. W., Carlson, C. A., Church, M., Kirchman, D. L., Smith, D., and Steward, G. (2001). The seasonal development of the bacterioplankton bloom in the Ross Sea, Antarctica, 1994-1997. Deep Sea Res. II 48, 4199-4221.

Ducklow, H. W., Dickson, M.-L., Kirchman, D. L., Steward, G., Orchardo, J., Marra, J., and Azam, F. (2000). Constraining bacterial production, conversion efficiency and respiration in the Ross Sea, Antarctica, JanuaryFebruary, 1997. Deep Sea Res. II 47, 3227-3247.

Dyhrman, S. T., Webb, E. A., Anderson, D. M., Moffett, J. W., and Waterbury, J. B. (2002). Cell-specific detection of phosphate stress in Trichodesmium from the Western North Atlantic. Limnol. Oceanogr. 47, 1832-1836.

Feng, Y., Hare, C. E., Rose, J. M., Handy, S. M., DiTullio, G. R., Lee,
P. A., Smith, W. O., Peloquin, J., Tozzi, S., Sun, J., Zhang, Y., Dunbar, R. B., Long, M. C., Sohst, B., Lohan, M., and Hutchins, D. A.(2010). Interactive effects of iron, irradiance and $\mathrm{CO} 2$ on Ross Sea phytoplankton. Deep Sea Res. I 57, 368-383.

Garcia, N. S., Sedwick, P. N., and DiTullio, G. R. (2009). Influence of irradiance and iron on the growth of colonial Phaeocystis antarctica: implications for seasonal bloom dynamics in the Ross Sea, Antarctica Aquat. Microb. Ecol. 57, 203-220.

Giovannoni, S. J., Tripp, J., Givan, S., Podar, M., Vergin, K. L., and Baptista, D., Bibbs, L., Eads, J., Richardson, T. H., Noordewier, M., Rappé, M. S., Short, J. M., Carrington, J. C., and Mathur, E. J. (2005). Genome streamlining in a cosmopolitan oceanic bacterium. Science 309, 1242-1245.

Gobler, C. J., Norman, C., Panzeca, C., Taylor, G. T., and SanudoWilhelmy, S. A. (2007). Effect of Bvitamins and inorganic nutrients on algal bloom dynamics in a coastal ecosystem. Aquat. Microb. Ecol. 49, 181-194.

Hale, M. S., Rivkin, R. B., Matthews, P., Agawin, N. S. R., and Li, W. K. W. (2006). Microbial response to a mesoscale iron enrichment in the NE subarctic pacific: heterotrophic bacterial processes. Deep Sea Res. II 53, 2231-2247.

Hall, J. A., and Safi, K. (2001). The impact of in situ Fe fertilization on the microbial food web in the Southern Ocean. Deep Sea Res. II 48, 2591-2613.

Helliwell, K. E., Wheeler, G. L., Leptos, K. C., Goldstein, R. E., and Smith, A. G. (2011). Insights into the evolution of vitamin B12 auxotrophy from sequenced algal genomes. Mol. Biol. Evol. doi: 10.1093/molbev/msr124. [Epub ahead of print].

Hutchins, D. A., Sedwick, P. N., DiTullio, G. R., Boyd, P. W., Queguiner, B., Griffiths, F. B., and Crossley, C. (2001). Control of phytoplankton growth by iron and silicic acid availablity in the subantarctic Southern Ocean: experimental results from the SAZ project. J. Geophys. Res. 106, 31559-31572. 
Hutchins, D. A., Sedwick, P. N., DiTullio, G. R., Boyd, P. W., Queguiner, B., Griffiths, F. B., and Crossley, C. (2001). Control of phytoplankton growth by iron and silicic acid availablity in the subantarctic Southern Ocean: experimental results from the SAZ project. J. Geophys. Res. 106, 31559-31572.

Karl, D. M. (2002). Nutrient dynamics in the deep blue sea. Trends Microbiol. 10, 410-418.

Kirchman, D. L., Meon, B., Cottrell, M. T., Hutchins, D. A., Weeks, D., and Bruland, K. W. (2000). Carbon versus iron limitation of bacterial growth in the California upwelling region. Limnol. Oceanogr. 45, 1681-1688.

Koch, F., Marcoval, M. A., Panzeca, C., Bruland, K. W., Sanudo-Wilhelmy, S. A., and Gobler, C. J. (2011). The effect of vitamin B12 on phytoplankton growth and community structure in the Gulf of Alaska. Limnol. Oceanogr. 56, 1023-1034.

LaRoche, J., Boyd, P. W., McKay, R. M. L., and Geider, R. J. (1996). Flavodoxin as an in situ marker for iron stress in phytoplankton. Nature 382, 802-805.

Leventer, A., and Dunbar, R. B. (1996). Factors influencing the distribution of diatoms and other algae in the Ross Sea. J. Geophys. Res. 101, 18489-18500.

Marchant, H. J. (2005). “Cyanophytes," in Antarctic Marine Protists, eds F. J. Scott and H. J. Marchant (Canberra: Australian Biological Resources Study), 324-325.

Martin, J. H., Fitzwater, S. E., and Gordon, R. M. (1990). Iron deficiency limits phytoplankton productivity in Antarctic waters. Global Biogeochem. Cycles 4. 5-12.

Menzel, D. W., and Spaeth, J. P. (1962). Occurrence of vitamin B12 in the Sargasso Sea. Limnol. Oceanogr. 7, 151-154.

Morel, F. M. M. (1987). Kinetics of nutrient uptake and growth in phytoplankton. J. Phycol. 23, 137-150.

Oliver, J. L., Barber, R. T., Smith, W. O., and Ducklow, H. W. (2004). The heterotrophic bacterial response during the Southern Ocean iron experiment (SOFeX). Limnol. Oceanogr. 49, 2129-2140.

Olson, R. J., Sosik, H. M., Chekalyuk, A. M., and Shalapyonok, A. (2000). Effects of iron enrichment on phytoplankton in the Southern Ocean during late summer: active fluorescence and flow cytometric analyses. Deep Sea Res. II 47, 3181-3200.

Pakulski, J. D., Coffin, R. B., Kelley, C. A., Holder, S. L., Downer, R., and Aas,
P., Lyons, M. M., and Jeffrey, W. H. (1996). Iron stimulation of Antarctic bacteria. Nature 383, 133-134.

Panzeca, C., Beck, A. J., Tovar-Sanchez, A., Segovia-Zavala, J., Taylor, G. T., Gobler, C. J., and Sañudo-Wilhelmy, S. A. (2009). Distributions of dissolved vitamin B12 and Co in coastal and open-ocean environments estuarine, coastal and shelf. Sciences 85 , 223-230.

Panzeca, C., Tovar-Sanchez, A., Agusti, S., Reche, I., Duarte, M., Taylor, G. T., and Sanudo-Wilhelmy, S. A. (2006). B vitamins as regulators of phytoplankton dynamics. Eos Trans. AGU 87, 593-596.

Porter, K. G., and Feig, Y. G. (1980). The use of DAPI for identifying and counting aquatic microflora. Limnol. Oceanogr. 25, 943-948.

Price, N. M., Harrison, G. I., Hering, J. G., Hudson, R. J., Nirel, P. M. V., Palenik, B., and Morel, F. M. M. (1988/1989). Preparation and chemistry of the artificial algal culture medium Aquil. Biol. Oceanogr. 6, 443-461.

Putt, M., Miceli, G., and Stoecker, D. (1994). Association of bacteria with Phaeocystis sp. in McMurdo sound, Antarctica. Mar. Ecol. Prog. Ser. 105, 179-189.

Raux, E., Schubert, H. L., and Warren, M. J. (2000). Biosynthesis of cobalamin (vitamin B12): a bacterial conundrum. Cell. Mol. Life Sci. 57, 1880-1893.

Rodionov, D. A., Vitreschak, A. G., Mironov, A. A., and Gelfand, M. S. (2003). Comparative genomics of the vitamin B12 metabolism and regulation in prokaryotes. J. Biol. Chem. 278, 41148-41159.

Roling, W. F. M. (2007). Do microbial numbers count? Quantifying the regulation of biogeochemical fluxes by population size and cellular activity. FEMS Microbiol. Ecol.62, 202-210.

Rose, J. M., Feng, Y., DiTullio, G. R., Dunbar, R. B., Hare, C. E., and Lee, P. A., Lohan, M., Long, M., Smith, W. O., Sohst, B., Tozzi, S., Zhang, Y., and Hutchins, D. A. (2009). Synergistic effects of iron and temperature on Antarctic phytoplankton and microzooplankton assemblages. Biogeosciences 6, 3131-3147.

Roth, J. R., Lawrence, J. G., and Bobik, T. A. (1996). Cobalamin (coenzyme B12): synthesis and biological significance. Annu. Rev. Microbiol. 50, 137-181.

Saito, M. A., Goepfert, T. J., Noble, A. E., Bertrand, E. M., Sedwick, P. N., and DiTullio, G. R. (2010). A seasonal study of dissolved cobalt in the Ross Sea, Antarctica: micronutrient behavior, absence of scavenging, and relationships with $\mathrm{Zn}, \mathrm{Cd}$, and P. Biogeosciences 7, 6387-6439.

Saito, M. A., and Goepfert, T. J. (2008). Zinc-cobalt colimitation of Phaeocystis antarctica. Limnol. Oceanogr. 53, 266 .

Saito, M. A., Goepfert, T. J., and Ritt, J. T. (2008). Some thoughts on the concept of colimitation: three definitions and the importance of bioavailability. Limnol. Oceanogr. 53, 276-290.

Sañudo-Wilhelmy, S. A., Okbamichael, M., Gobler, C. J., and Taylor, G. T. (2006). Regulation of phytoplankton dynamics by vitamin B12. Geophys. Res. Lett. 33.

Scott, F. J., and Marchant, H. J. (eds). (2005). Antarctic Marine Protists. Canberra: Australian Biological Resources Study, 295-307.

Sedwick, P., and DiTullio, G. R. (1997). Regulation of algal blooms in Antarctic shelf waters by the release of iron from melting sea ice. Geophys. Res. Lett. 24, 2515-2518.

Sedwick, P. N., DiTullio, G. R., and Mackey, D. J. (2000). Iron and manganese in the Ross Sea, Antarctica: seasonal iron limitation in Antarctic shelf waters. J. Geophys. Res. 105, 11321-11336.

Smith, W. O. J., and Nelson, D. M. (1985). Phytoplankton bloom produced by a receding ice edge in the Ross Sea: spatial coherence with the density. Science 227 , 163-166.

Sunda, W., and Huntsman, S. A. (1992). Feedback interactions between zinc and phytoplankton in seawater. Limnol. Oceanogr. 37, 25-40.

Swift, D. (1981). Vitamin levels in the Gulf of Maine and ecological significance of vitamin B12 there. J. Mar. Res. 39, 375-403.

Tang, Y. Z., Koch, F., and Gobler, C. J. (2010). Most harmful algal bloom species are vitamin B1 and B12 auxotrophs. Proc. Natl. Acad. Sci. U.S.A. 107, 20756-20761.

Taylor, G. T., and Sullivan, C. W. (2008). Vitamin B12 and cobalt cycling among diatoms and bacteria in antarctic sea ice microbial communities. Limnol. Oceanogr. 53, 1862-1877.

Tortell, P., Maldonado, M., and Price, N. (1996). The role of heterotrophic bacteria in iron-limited ocean ecosystems. Nature 383, 330-332.

Van Leeuwe, M. A., and Stefels, J. (1998). Effects of iron and light stress on the biochemical composition of antarctic Phaeocys tis sp. (Prymnesiophyceae). II. Pigment composition. J. Phycol. 34, 496-503.

Webb, E. A., Moffett, J. W., and Waterbury, J. B. (2001). Iron stress in open ocean cyanobacteria (Synechococcus, Trichodesmium, and Crocosphaera): identification of the IdiA protein. Appl. Environ. Microbiol.67, 5444-5452.

Welschmeyer, N. A. (1994). Fluorometric analysis of chlorophyll a in the presence of chlorophyll $b$ and pheopigments. Limnol. Oceanogr. 39, 1985-1992.

Zapata, M., Rodriguez, F., and Garrido, J. L. (2000). Separation of chlorophylls and carotenoids from marine phytoplankton: a new HPLC method using a reversed phase C8 column and pyridine-containing mobile phases. Mar. Ecol. Prog. Ser. 195, 29-45.

Zettler, E. R., Olson, R. J., Binder, B. J., Chisholm, S. W., Fitzwater, S. E., and Gordon, M. R. (1996). Iron-enrichment bottle experiments in the equatorial Pacific: responses of individual phytoplankton cells. Deep Sea Res. II 43, 1017-1029.

Zhang, Y., Rodionov, D. A., Gelfand, M. S., and Gladyshev, V. N. (2009). Comparative genomics analysis of nickel, cobalt, and vitamin B12 utilization. BMC Genomics 10, 78. doi: 10.1186/1471-216410-78

Conflict of Interest Statement: The authors declare that the research was conducted in the absence of any commercial or financial relationships that could be construed as a potential conflict of interest.

Received: 07 February 2011; accepted: 13 July 2011; published online: 15 August 2011.

Citation: Bertrand EM, Saito MA, Lee $P A$, Dunbar RB, Sedwick PN and DiTullio GR (2011) Iron limitation of a springtime bacterial and phytoplankton community in the Ross Sea: implications for vitamin $B_{12}$ nutrition. Front. Microbio. 2:160. doi: 10.3389/fmicb.2011.00160 This article was submitted to Frontiers in Aquatic Microbiology, a specialty of Frontiers in Microbiology. Copyright (C) 2011 Bertrand, Saito, Lee, Dunbar, Sedwick and DiTullio. This is an open-access article subject to a nonexclusive license between the authors and Frontiers Media SA, which permits use, distribution and reproduction in other forums, provided the original authors and source are credited and other Frontiers conditions are complied with. 